\title{
資
}

料

農業気象 (J. Agric. Meteorol.) 57 (4): 201-207, 2001

\section{Investigation for Photosynthetically Active Radiation Regime in the Mongolian Grain Farm Region}

\author{
Nas-Urt Tugusuren* and Tamio Takamura** \\ * Mongolian State Technical University, Ulaanbaatar-46, Mongolia \\ ** Center for Environmental Remote Sensing, Chiba University, \\ Chiba, 263-8522 Japan
}

\begin{abstract}
This article discusses common features of photosynthetically active radiation (PAR) in the Mongolian grain farm region during the period of 1986 to 1996. The quantitative characteristics of solar radiation, such as direct, diffuse and global radiation are evaluated in the study through the long term trend.

The mean pattern of seasonal variation of PAR shows that the yearly minimum global (direct + diffuse) PAR is $68.9 \pm 7.6 \mathrm{MJ} /\left(\mathrm{m}^{2}\right.$ month $)$ in December while the maximum is $307.5 \pm 10.3 \mathrm{MJ} /\left(\mathrm{m}^{2}\right.$ month $)$ in May. The yearly summation is $2.22 \pm 0.07 \mathrm{GJ} /\left(\mathrm{m}^{2} \mathrm{yr}\right)$ and is very stable compared with monthly variations.
\end{abstract}

Key words: Solar radiation, PAR, Mongolian grain farm region, Mongolian grassland.

\section{Introduction}

Solar radiation is one of the primary factors affecting plant growth and metabolism. Plants utilize atmospheric gases to create organic substances through the photosynthetic process. This report uses the term Photosynthetically Active Radiation (PAR), where the wavelength is within the spectral range of $380-710 \mathrm{~nm}$. To determine the major characteristics of photosynthetic productivity, monthly and yearly amounts of PAR were determined for the grain farm region of Mongolia. Additionally, the phenomenon of PAR flux was investigated. As the Mongolian harvest is especially sensitive to the variation of PAR amounts, this study is important for Mongolian agriculture.

Mongolian agriculture is strongly dominated by the geographical location and its climate. Spring and summer seasons have a long daytime and sunshine, while winter has a short day time but almost all clear days due to high pressure systems. The study is complicated by the fact that the physiological

Received on August 25, 2000.

Accepted on July 31, 2001. diversities of plants are determined by the Mongolian climate and weather patterns. It is imperative to gather data on these physiological plant processes, yet data on this point has been insufficient.

In this study, we used investigative data at the Ugtaal Solar Station $\left(48^{\circ} 3^{\prime} \mathrm{N}, 105^{\circ} 25^{\prime} \mathrm{E}, 1160 \mathrm{~m}\right.$ above the mean sea level), which is located in the central agricultural zone of Mongolia. The average features of Ugtaal include a yearly mean temperature of $-1.4^{\circ} \mathrm{C}$ and $249 \mathrm{~mm}$ a year in precipitation, computed from the last 30 years of meteorological data. Land is covered with snow for 157 to 161 days a year. The vegetation period is limited to 92 to 128 days a year.

Data were collected at the station for every hour in the daytime during 1986-1996. In order to measure the PAR received at the earth's surface, a thermo-electric actinometer (AT-50) was mounted. This instrument has two filters (BS-8, KS-19), which can selectively pass only PAR (Batsukh et al., 1982). The direct radiation in the full wavelength and the direct PAR can be obtained by the filter operation, manually. We simultaneously measured diffuse radiation using a thermo-electric pyranometer (M-80M) 
with a black and white type sensor. With this instrument, the global and diffuse radiation can be observed with and without a shadow disk for direct solar flux (Tugjsuren, 1996).

\section{Direct Photosynthetic Active Radiation (SPAR)}

The PAR portion of daily-integrated radiation depends on the spectral content of two kinds of radiation, direct and diffuse radiation. The global radiation can be expressed by the summation of both types of radiation. Maximum energy in the spectrum of direct solar radiation is center around $480-550 \mathrm{~nm}$ at the highest solar elevation angle, and moves to longer wavelengths as solar altitude decreases, due to scattering by atmospheric particles.

The portion of SPAR in direct solar radiation flux changes depending on not only solar altitude, but also absorption gases, and aerosol amount in the cloud-free atmosphere as well as cloud amount in the cloudy atmosphere. For PAR flux changes, conversion coefficients from the whole solar radiation spectrum at the surface to the PAR may be evaluated in limited use. The first estimate of conversion coefficient $C_{s}$ from the direct radiation in the whole spectrum to the corresponding SPAR is derived from the theoretical spectral distribution of radiation. $C_{d}$ and $C_{q}$ can be defined as conversion coefficients for diffuse and global solar radiation in a similar way. These coefficients have also been determined experimentally by many researchers for different climaticgeographical areas (e.g., Batsukh, 1989; Batsukh et al., 1988).

While $C_{s}$ is dependent on solar elevation angle in general, as pointed out by Tooming (1977), an effective conversion coefficient $C_{\text {sef }}$ can be defined as the ratio of the daily and/or monthly means of SPAR to those in the whole wavelength by actinometric measurements:

$$
C_{\text {sef }}=\frac{\sum S_{p h}}{\sum S},
$$

where $S$ and $S_{p h}$ are daily- or monthly-integrated direct solar radiation and SPAR, respectively. In a similar manner, effective conversion coefficients of diffuse and global radiation are defined by the following formulas;

$$
\begin{aligned}
C_{q e f} & =\frac{\sum Q_{p h}}{\sum Q}, \\
C_{d e f} & =\frac{\sum D_{p h}}{\sum D},
\end{aligned}
$$

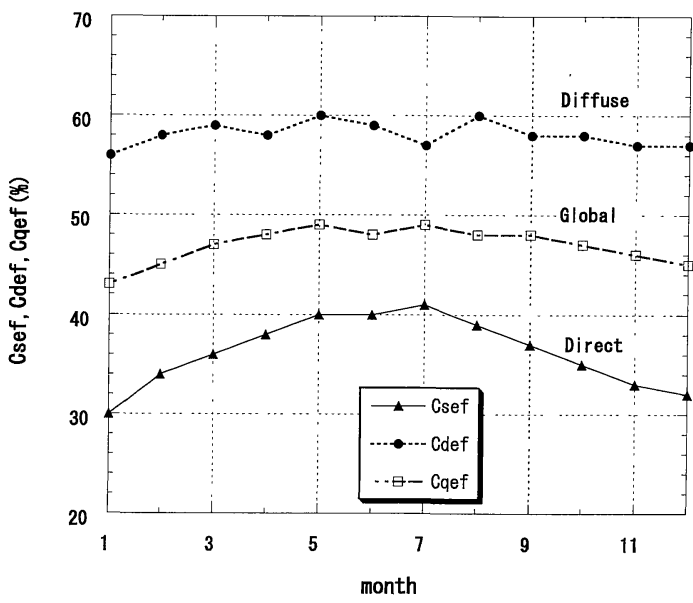

Fig. 1. The monthly variation of effective conversion coefficients, $C_{s e}, C_{d e f}$, and $C_{q e f}$, which are ratios of direct, diffuse and global PAR to the corresponding solar radiation flux in the whole wavelength, respectively.

$$
\begin{aligned}
& \Sigma Q_{p h}=\Sigma D_{p h}+\Sigma S_{p h}, \\
& \Sigma Q=\Sigma D+\Sigma S .
\end{aligned}
$$

In these equations, variables $D$ and $Q$ denote diffuse and global solar radiation, and the suffix $p h$ means the spectrum region for active photosynthetic radiation. Researchers have found methods for determination of coefficients $C_{s}, C_{d}, C_{d e f}, C_{q}, C_{q e f}$ (Tooming, 1977; Batsukh, 1989; Batsukh et al., 1982). For example, Efimova (1977) determined average values of $C_{s}=0.43, C_{d}=0.57$ theoretically. Tooming (1977) and our investigation can provide these values of $C_{s e f}$, $C_{d e f}$ and $C_{q e f}$, which are estimated from experimental data.

Figure 1 shows the seasonal trends of these coefficients derived from Ugtaal data during the period of 1986-1996. The conversion coefficient, $C_{\text {sef }}$, of direct solar radiation has a relatively large variation of $0.30-0.41$ in the mean seasonal trend. This is reflected by the fact that the direct solar radiation is more sensitive to the solar and atmospheric condition compared with other coefficients.

From our investigations, it was shown that yearly input of SPAR at territory Ugtaal under normal conditions ranges from 926.4 to $1,149.8 \mathrm{MJ} /\left(\mathrm{m}^{2} \mathrm{yr}\right)$, as seen in Table 1. Despite the relatively constant amount of solar energy received at the earth's surface annually, its quantitative amounts for a monthly mean are significantly changeable. 
Table 1. Monthly integrated Direct Photosynthetically Active Radiation (SPAR; MJ $/\left(\mathrm{m}^{2}\right.$ month)) during the period of 1986-1996 at Ugtaal in Mongolia. "Sum" means the summation of monthly amount for a year, and "average" and "Std dev" are the average and standard deviation during the period for month and "Sum".

\begin{tabular}{|c|c|c|c|c|c|c|c|c|c|c|c|c|c|}
\hline Month & 1 & 2 & 3 & 4 & 5 & 6 & 7 & 8 & 9 & 10 & 11 & 12 & Sum \\
\hline 1986 & & & & & & 127.4 & 142.6 & 133.2 & 107.3 & 72.0 & 43.6 & 27.4 & $(653.5)$ \\
\hline 1987 & 30.6 & 60.5 & 101.9 & 107.6 & 127.1 & 134.6 & 127.8 & 111.2 & 108.4 & 70.6 & 39.6 & 23.8 & $1,043.7$ \\
\hline 1988 & 29.9 & 59.0 & 99.7 & 106.2 & 131.0 & 137.2 & 142.6 & 133.9 & 108.0 & 71.3 & 42.1 & 23.0 & $1,083.9$ \\
\hline 1989 & 39.2 & 58.3 & 90.0 & 128.9 & 128.5 & 155.5 & 114.1 & 126.7 & 99.0 & 70.9 & 44.1 & 30.0 & $10,85.2$ \\
\hline 1990 & 43.9 & 57.9 & 85.1 & 144.7 & 151.5 & 135.7 & 137.0 & 84.6 & 115.6 & 95.4 & 54.4 & 44.0 & $1,149.8$ \\
\hline 1991 & 47.3 & 73.1 & 94.7 & 139.7 & 162.4 & 127.4 & 136.4 & 119.2 & 61.9 & 81.4 & 38.2 & 16.9 & $1,098.6$ \\
\hline 1992 & 39.4 & 57.1 & 69.2 & 98.6 & 123.3 & 164.6 & 136.7 & 82.9 & 64.6 & 71.1 & 21.3 & 25.3 & 954.1 \\
\hline 1993 & 20.0 & 47.3 & 89.1 & 128.3 & 138.3 & 106.7 & 72.4 & 92.2 & 74.4 & 89.6 & 49.6 & 18.5 & 926.4 \\
\hline 1994 & 41.0 & 66.3 & 98.0 & 128.6 & 162.7 & 112.7 & 110.1 & 112.2 & 98.8 & 90.5 & 49.9 & 20.5 & $1,091.2$ \\
\hline 1995 & 42.9 & 67.1 & 99.0 & 130.3 & 159.5 & 127.0 & 114.2 & 113.2 & 97.4 & 90.1 & 48.8 & 21.1 & $1,110.6$ \\
\hline 1996 & 40.1 & 66.7 & 100.1 & 138.4 & 160.4 & 134.5 & 115.1 & 111.4 & 109.1 & 88.2 & 49.0 & 22.2 & $1,135.2$ \\
\hline Average & 37.4 & 61.3 & 92.7 & 125.1 & 144.5 & 133.0 & 122.6 & 111.0 & 95.0 & 81.0 & 43.7 & 24.8 & $1,067.9$ \\
\hline Std dev & 8.2 & 7.2 & 10.0 & 15.7 & 16.4 & 16.5 & 20.7 & 17.8 & 19.0 & 10.0 & 8.9 & 7.4 & 73.5 \\
\hline
\end{tabular}

A specific feature of seasonal variation of SPAR has mean values of $24.8 \mathrm{MJ} /\left(\mathrm{m}^{2}\right.$ month $)$ in December as a minimum and $144.5 \mathrm{MJ} /\left(\mathrm{m}^{2}\right.$ month $)$ in May as a maximum during the period of 1986-1996. The maximum values are $162.7-164.6 \mathrm{MJ} /\left(\mathrm{m}^{2}\right.$ month $)$ observed in May or June. The minimum value of $\mathrm{SPAR}$ is $16.9 \mathrm{MJ} /\left(\mathrm{m}^{2}\right.$ month $)$ in December. From winter to summer, SPAR increases relatively fast, especially from February to April. Generally, due to the solar elevation increasing towards the summer solstice, SPAR should increase until June, but the peak SPAR has been in May due to the climatic conditions in Mongolia. A sharp decrease of SPAR is also shown in September to November.

\section{Diffuse Photosynthetically Active Radiation} (DPAR)

The atmosphere is non-transparent due to many kinds of suspended material, which consists of molecules, different types of aerosols and other bigger particles, such as cloud particles, rain droplets or snow/ice particles. Downward diffuse radiation at the surface depends basically on these atmospheric constituents and surface albedo in some cases.

The DPAR flux under whole atmospheric conditions shows $163.5 \mathrm{MJ} /\left(\mathrm{m}^{2}\right.$ month $)$ in May as the mean maximum and $41.1 \mathrm{MJ} /\left(\mathrm{m}^{2}\right.$ month $)$ in January as the mean minimum during 1986-1996. The peak value is $182.0 \mathrm{MJ} /\left(\mathrm{m}^{2} \mathrm{month}\right)$ in May, while $31.1 \mathrm{MJ} /\left(\mathrm{m}^{2}\right.$ month $)$ in January is a minimum level, as shown in Table 2.

It may be said that natural aerosols increase in spring and autumn in Mongolia, with relation to dust and sand storms, while strong cloud developments are dominant in summer. The cloud particles consisting of water droplets or ice crystals, are effective scatterers of solar radiation. Specifically, strong scattering and small absorption by clouds are sometimes connected with upper-level or well-developed clouds. Middle layer clouds can also affect this process. Naturally, the measured flux of diffuse radiation must depend on cloud amount and its inhomogeneity. Transition of stratus to nimbostratus cloud may cause an increase in ratio of diffuse radiation.

Comparatively, high value of the surface albedo can be observed in winter due to snow cover. Multiple scattering between the surface and the atmosphere is enhanced for high surface albedo, causing an increase in diffuse radiation. This effect may appear in DPAR observed from November to March in territory Ugtaal. In this region, a heavy sandstorm, like a yellow-sand event in the far-east Asia happens sometimes from March to May, so that the DPAR may increase as shown in Fig. 2.

\section{Global Photosynthetically Active Radiation (QPAR)}

Global solar radiation is one of the most essential factors for vegetation. Results of the investigation show that a mean value of integrated solar radiation over all wavelengths at Ugtaal for 11 years (1986$1996)$, is $4.4-4.7 \mathrm{GJ} / \mathrm{m}^{2}$ for the whole year, and 2.3$2.7 \mathrm{GJ} /\left(\mathrm{m}^{2} \mathrm{yr}\right)$ for the vegetation period (May-Sep- 
Table 2. Same as Table 1 except for Diffuse Photosynthetically Active Radiation (DPAR; MJ $/\left(\mathrm{m}^{2}\right.$ month)).

\begin{tabular}{crrrrrrrrrrrrr}
\hline Month & 1 & \multicolumn{1}{c}{2} & \multicolumn{1}{c}{3} & \multicolumn{1}{c}{4} & 5 & 6 & 7 & 8 & 9 & 10 & 11 & 12 & Sum \\
\hline 1986 & & & & & & 158.4 & 151.9 & 137.5 & 96.5 & 74.9 & 50.0 & 42.1 & $(711.3)$ \\
1987 & 45.0 & 59.8 & 106.2 & 136.8 & 172.1 & 159.1 & 151.9 & 132.1 & 95.0 & 75.2 & 48.9 & 39.2 & $1,221.3$ \\
1988 & 46.1 & 62.3 & 120.2 & 133.9 & 172.4 & 160.2 & 153.7 & 136.1 & 95.0 & 75.2 & 49.3 & 45.0 & $1,249.4$ \\
1989 & 38.9 & 49.3 & 96.8 & 111.6 & 162.4 & 141.8 & 149.0 & 117.4 & 89.3 & 59.8 & 46.3 & 40.2 & $1,102.8$ \\
1990 & 37.1 & 54.0 & 88.4 & 96.5 & 169.9 & 147.2 & 125.3 & 125.6 & 82.8 & 61.2 & 50.0 & 46.7 & $1,084.7$ \\
1991 & 35.9 & 50.4 & 108.7 & 126.4 & 153.0 & 156.2 & 128.5 & 114.1 & 93.9 & 70.2 & 48.2 & 48.2 & $1,133.7$ \\
1992 & 51.9 & 67.8 & 121.4 & 161.7 & 182.0 & 147.6 & 139.4 & 132.4 & 93.9 & 73.5 & 61.1 & 43.2 & $1,275.9$ \\
1993 & 50.5 & 70.9 & 117.1 & 130.8 & 163.6 & 146.6 & 142.5 & 108.9 & 90.7 & 55.4 & 49.1 & 44.9 & $1,171.0$ \\
1994 & 34.4 & 41.9 & 94.5 & 106.3 & 157.3 & 139.4 & 148.8 & 130.2 & 90.5 & 60.1 & 50.5 & 46.4 & $1,100.3$ \\
1995 & 31.1 & 44.1 & 91.1 & 110.0 & 150.5 & 127.1 & 137.2 & 109.1 & 90.7 & 59.8 & 50.7 & 46.3 & $1,047.7$ \\
1996 & 40.0 & 51.2 & 100.2 & 111.2 & 151.4 & 138.5 & 142.4 & 132.6 & 91.2 & 60.0 & 49.9 & 43.0 & $1,111.6$ \\
\hline Average & 41.1 & 55.2 & 104.5 & 122.5 & 163.5 & 147.5 & 142.8 & 125.1 & 91.8 & 65.9 & 50.4 & 44.1 & $1,149.8$ \\
Std dev & 7.0 & 9.7 & 12.2 & 19.1 & 10.6 & 10.4 & 9.6 & 10.8 & 3.8 & 7.8 & 3.8 & 2.8 & 76.3 \\
\hline
\end{tabular}

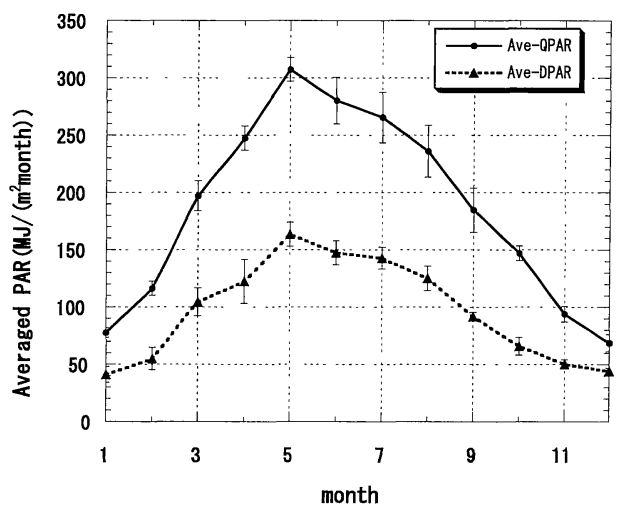

Fig. 2. Yearly-averaged QPAR and DPAR $\left(\mathrm{MJ} /\left(\mathrm{m}^{2}\right.\right.$ month $\left.)\right)$ for each month during the period of $1986-1996$ at Ugtaal in Mongolia.

tember).

There are wide and integrated data archives on geographical distribution of daily, seasonal and yearly global radiation in China and Russia surrounding the Mongolian territory. This approach can fill up a white map of Mongolia with the complementary data.

Due to a difference of daytime duration of 1.6-1.9 times between winter and summer for all Mongolian areas, monthly QPAR increases around 3-4 times. For example, according to our data in Ugtaal, daytime duration increases from $260 \mathrm{~h}$ in December to $481 \mathrm{~h}$ in July. In connection with such an increase of daytime duration, an incoming QPAR changes in Ugtaal from $68.9 \mathrm{MJ} /\left(\mathrm{m}^{2}\right.$ month $)$ in average in December to $307.5 \mathrm{MJ} /\left(\mathrm{m}^{2}\right.$ month $)$ in average in May, as shown in Table 3.

A rapid increase of monthly QPAR is also seen from February to May in Fig. 2, while a steep decrease starts from August. The maximal QPAR in average usually appears in May, but there are exceptional cases (See the data, 1989 and 1992) where the maximal month moves from May to June. The main reason for the shift of maximum QPAR may be the variation of cloudiness.

Table 3 shows that the annual variation of yearlyintegrated QPAR is quite stable $\left(2.22 \pm 0.06 \mathrm{GJ} /\left(\mathrm{m}^{2}\right.\right.$ $\mathrm{yr}))$ compared with the SPAR $\left(1.07 \pm 0.07 \mathrm{GJ} /\left(\mathrm{m}^{2}\right.\right.$ yr)). However, the monthly variation of SPAR for each year has a wide range from $11 \%$ in May to $30 \%$ in December. The stable input is very favorable for plant growth.

After Mt. Pinatubo's eruption (June 15, 1991), the volcanic dust extended from the tropical region to the polar region for several months. This effect to the PAR should be checked carefully, because the El Nino happened in the same period of April 1991September 1992. Pinatubo's effect might be possibly overlayed and/or mixed with the El Nino effect, but the global modification of cloud pattern due to the change of the atmospheric circulation system is not clear. Pinatubo's effect in Mongolia may be mainly due to an increase in the stratospheric aerosols, while the El Nino can modify the cloud pattern through an increase or decrease in the circulation system. The basic difference between them, i.e., aerosol or cloud effect, may appear in the difference in the trend of SPAR and QPAR. Figure 3a shows the large fluctuation during the period of 1991-1993 for the monthly data. Since the SPAR is attenuated directly 
Table 3. Same as Table 1 except for Global Photosynthetically Active Radiation (QPAR; MJ/(m² month)).

\begin{tabular}{cccccccccccccc}
\hline Month & 1 & 2 & 3 & 4 & 5 & 6 & 7 & 8 & 9 & 10 & 11 & 12 & Sum \\
\hline 1986 & & & & & & 285.8 & 294.5 & 270.7 & 203.8 & 146.9 & 93.6 & 69.5 & $(1,364.8)$ \\
1987 & 75.6 & 120.2 & 208.1 & 244.4 & 299.2 & 293.8 & 279.7 & 243.4 & 203.4 & 145.8 & 88.6 & 63.0 & $2,265.2$ \\
1988 & 75.9 & 121.3 & 219.9 & 240.1 & 303.5 & 297.4 & 296.3 & 270.0 & 203.0 & 146.5 & 91.4 & 68.0 & $2,333.3$ \\
1989 & 78.1 & 107.6 & 186.8 & 240.5 & 287.3 & 297.4 & 263.2 & 244.1 & 188.3 & 130.7 & 90.4 & 70.2 & $2,184.6$ \\
1990 & 81.0 & 111.9 & 173.5 & 241.2 & 321.4 & 282.9 & 262.3 & 210.2 & 198.4 & 156.6 & 104.4 & 90.7 & $2,234.5$ \\
1991 & 83.2 & 123.5 & 203.4 & 266.0 & 315.4 & 283.7 & 264.9 & 233.3 & 155.9 & 151.6 & 86.4 & 65.2 & $2,232.5$ \\
1992 & 82.8 & 124.9 & 190.6 & 260.3 & 305.3 & 312.2 & 276.1 & 215.3 & 158.5 & 144.6 & 82.4 & 68.5 & $2,221.5$ \\
1993 & 70.5 & 118.2 & 206.2 & 259.1 & 301.9 & 253.3 & 214.9 & 201.1 & 165.1 & 145.0 & 98.7 & 63.4 & $2,097.4$ \\
1994 & 75.4 & 108.2 & 192.5 & 234.8 & 320.0 & 251.1 & 258.9 & 242.4 & 189.3 & 150.6 & 100.4 & 66.9 & $2,190.5$ \\
1995 & 74.0 & 111.2 & 190.1 & 240.3 & 310.0 & 254.1 & 254.1 & 222.3 & 188.1 & 149.9 & 99.5 & 67.4 & $2,158.3$ \\
1996 & 80.1 & 117.9 & 200.3 & 249.6 & 311.3 & 273.0 & 257.5 & 244.0 & 200.3 & 148.2 & 98.9 & 65.2 & $2,246.8$ \\
\hline Average & 77.7 & 116.5 & 197.1 & 247.6 & 307.5 & 280.4 & 265.7 & 236.1 & 186.7 & 146.9 & 94.1 & 68.9 & $2,216.5$ \\
Std dev & 4.1 & 6.3 & 13.1 & 10.6 & 10.3 & 20.4 & 22.2 & 22.6 & 18.4 & 6.4 & 6.8 & 7.6 & 64.0 \\
\hline
\end{tabular}

by aerosols and cloud, the fluctuations in the period must be affected by an increase of these suspended particles. If the cloud amount and its optical thickness are increasing over the usual level, the amount of QPAR should be decreasing except for optically thin cloud cases. In the case of aerosol, its effect is a little different from clouds, because the increase in DPAR can compensate for the decrease in SPAR.

Figure 3 b shows no remarkable decrease in QPAR during this period except for September, compared with Fig. 3 a. This tendency of QPAR might suggest that the fluctuation of SPAR is caused by an increase in aerosol. Pinatubo's effect over Japan after several months was estimated at about $0.15-0.20$ in optical thickness at $0.53 \mu \mathrm{m}$ (Takamura et al., 1994). This is in accordance with the attenuation of SPAR. However, as an optically thin cloud such as cirrus has a similar effect, it is difficult to separate both effects completely only from these parameters.

The start and end time of the vegetation period is a quite important parameter for agriculture. The vegetation in Mongolia becomes active when the mean air temperature exceeds 5 degrees. The decisive factor for active vegetation is not only a latitudinal location but also altitude, with a decrease by 6.5 $\mathrm{K}$ in average temperature for each $\mathrm{km}$ increase in altitude. The QPAR is basically independent of altitude, but the growth process of plants is strongly controlled by QPAR and environmental temperature as well as water.

The geographical conditions of Mongolia show a continental climate type due to location and elevation (more than $80 \%$ of territory is located at 1,000 $\mathrm{m}$ or higher). Therefore, the duration of vegetation
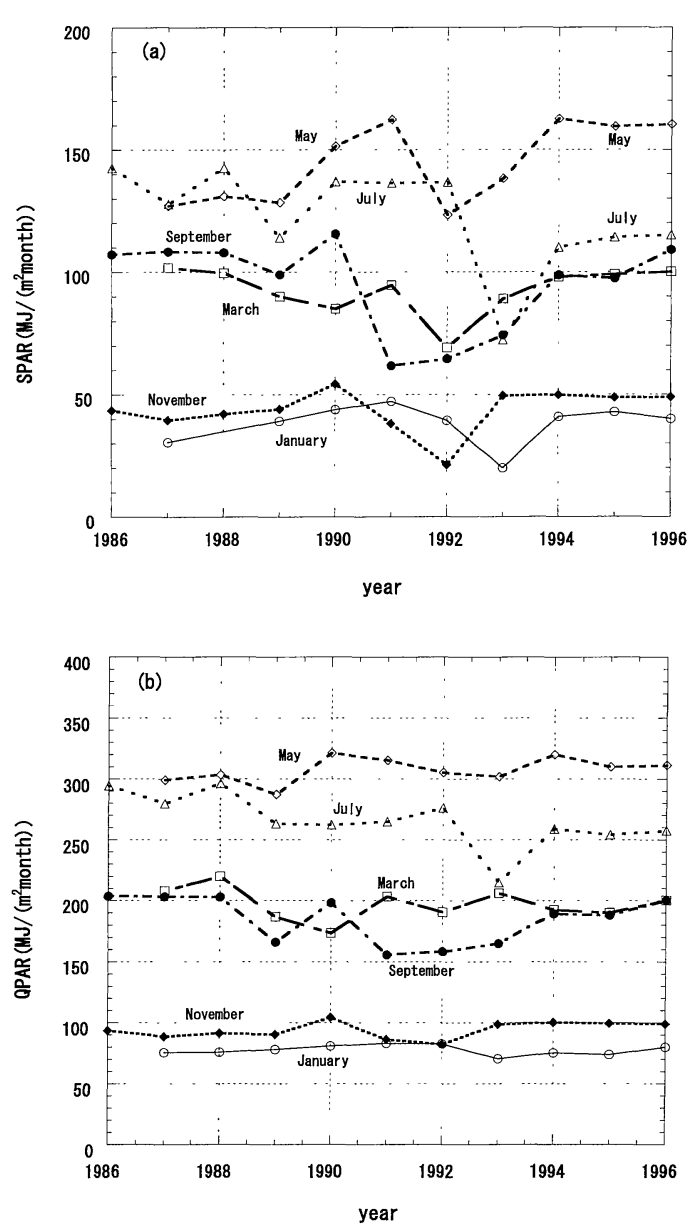

Fig. 3. Long term trend of monthly SPAR (a) and QPAR data (b). The SPAR is more sensitive to atmospheric conditions such as aerosol or cloud loading, than the QPAR. 


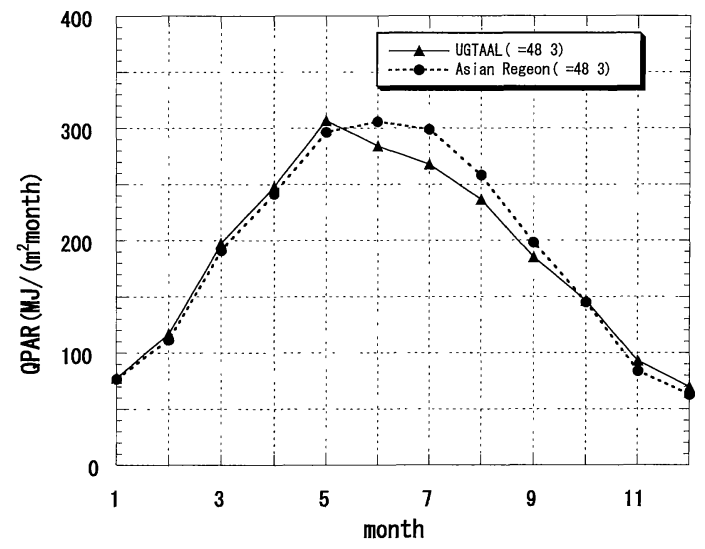

Fig. 4. Comparison of QPAR between Ugtaal and the neighboring Asian region. Both places are at the same latitude, but have different altitudes.

period is relatively shorter than that in neighboring countries, where the mean altitude is much lower than the Mongolian territories.

For comparison, Figure 4 represents monthly trends of QPAR at territory of Ugtaal and Asian territory of the former USSR (now in Russia), placed at almost the same latitude, but about $800 \mathrm{~m}$ in altitude. The yearly integration of QPAR in Ugtaal $\left(2,217 \mathrm{MJ} /\left(\mathrm{m}^{2} \mathrm{yr}\right)\right)$ is almost the same as that of Asian territory $\left(2,271 \mathrm{MJ} /\left(\mathrm{m}^{2} \mathrm{yr}\right)\right)$, but the difference in vegetation period is larger. It should be noted that the QPAR is one of the most important factors for vegetation, and also the altitude of land should be considered for vegetation activities. Plant growth is very sensitive to differences in temperature due to altitude, especially where the mean temperature is below freezing.

\section{Summary}

(1) The mean yearly input of direct PAR (SPAR) at the territory of Ugtaal is $1,067.9 \mathrm{MJ} /\left(\mathrm{m}^{2}\right.$ yr) with a variation of 926.4 to $1,149.8 \mathrm{MJ} /\left(\mathrm{m}^{2} \mathrm{yr}\right)$ through the observation period of 1986-1996. One of the specific features of seasonal trends of SPAR shows that the maximal and minimal input during the observation period are in May as $144.5 \pm 16.4$ and in December as $24.8 \pm 7.4 \mathrm{MJ} /\left(\mathrm{m}^{2}\right.$ month), respectively.

(2) The maximal peak of diffuse PAR (DPAR) shows $163.5 \pm 10.5 \mathrm{MJ} /\left(\mathrm{m}^{2}\right.$ month $)$ in May during the period. This may be due to sand storms in this season. The minimal DPAR is $41.2 \pm 7.0 \mathrm{MJ} /\left(\mathrm{m}^{2}\right.$ month) in January in the same period.

(3) Monthly input of global PAR(QPAR) at the territory of Ugtaal varies from $68.9 \pm 7.6 \mathrm{MJ} /\left(\mathrm{m}^{2}\right.$ month) in December to $307.5 \pm 10.3 \mathrm{MJ} /\left(\mathrm{m}^{2}\right.$ month $)$ in May. Yearly input of QPAR is $2.2 \mathrm{GJ} /\left(\mathrm{m}^{2} \mathrm{yr}\right)$ and very stable within a standard deviation of $2.9 \%$ during the period.

\section{References}

Batsukh, G., Sitnik, G.F., Khaltar, D. and Tugjsuren, N., 1988: Variety of spectral content of direct solar radiation in Ulaanbaatar. Proceeding of "Nature Environment Protection Problems," pp. 38-50 (in Mongolia).

Batsukh, G., 1989: Investigation of spectral content of solar radiation in some points of Mongolian People's Republic. PhD thesis, Mongolian State University, 122 pp. (in Mongolia).

Batsukh, G., Tugjsuren, N., Khaltar, D. and Filippov, A. Kh., 1982: Spectral coefficients and reduction multification light filters, used in scientific works on atmospheric optics at Mongolian State University. Mongolian State University Scientific Transaction, 79, 123-132 (in Mongolia).

Efimova, N.A., 1977: Radiation factors of plant cover. Hydrological Printing House, Leningrad, 150 pp. (in Russian).

Tooming, Kh., 1977: Solar radiation and PAR utilization in crops. Hydrological Printing House, Leningrad, 200 pp. (in Russian).

Takamura, T., Sasano, Y. and Hayasaka, T., 1994: Tropospheric aerosol optical properties derived from lidar, sun photometer, and optical particle counter measurements. Appl. Opt., 33, 7132-7140.

Tugjsuren, N., 1996: Investigation of solar radiation regime on dry and cool zone for crop-growing region of Mongolia. In Science technology report. Science and Technology Center, Ulaanbaatar, 75 pp. (in Mongolian). 


\section{モンゴル穀物生産地域における光合成有効放射量の計測 \\ Nas-Urt TugJsuren* • 高村民雄** \\ $\left(\begin{array}{c}* \text { Mongolian State Technical University } \\ * * \text { 千葉大学環境リモートセンシング研究センター }\end{array}\right)$}

要約

モンゴルの穀物生産地域で，1986 年から 1996 年ま での 11 年間にわたって, 光合成有効放射量（PAR）の 測定が行われた。この期間の, 直達, 散乱, 全天日射量 (直達十散乱) の月積算量の解析が行われ，この地域にお ける光合成有効放射量の季節的，経年的な特徵が明らか にされた。

その結果，この観測期間の平均として，全天日射量の
月平均の最小は 12 月で $68.9 \pm 7.6 \mathrm{MJ} /\left(\mathrm{m}^{2} \mathrm{month}\right)$, 最大は 5 月で $307.5 \pm 10.3 \mathrm{MJ} /\left(\mathrm{m}^{2}\right.$ month $)$ である。 年間の積算量は, $2.22 \pm 0.07 \mathrm{GJ} /\left(\mathrm{m}^{2} \mathrm{yr}\right)$ であり, 月平 均の経年的変動に比べて, 年積算量は経年的にかなり安 定していることがわかった。

キーワード: 日射量, 光合成有効放射量, モンゴル穀物 生産地域, モンゴル草原 